\title{
The accuracy of modelling of the thermal cycle of a compresion ignition engine
}

\author{
The results of numerical analysis the combustion process in turbocharged CI engine $6 C T 107$ are presented in the \\ paper. Engine was installed on the ANDORIA's power generator of $100 \mathrm{kVA} / 80 \mathrm{~kW}$. The results of modelling the combu- \\ stion process for different angle setting fuel injection, compared with the results obtained by indicating the real engine. \\ Numerical analysis was performed in two programs, designed for three-dimensional modelling of the thermal cycle the \\ piston internal combustion engine, namely AVL FIRE and the KIVA-3V.
}

Keywords: combustion engine, modelling, combustion

Dokładność modelowania obiegu cieplnego silnika o zapłonie samoczynnym

\begin{abstract}
W artykule przedstawiono wyniki analizy numerycznej procesu spalania w doładowanym silniku spalinowym 6 CT107 o zapłonie samoczynnym, zainstalowanym na agregacie prądotwórczym firmy ANDORIA-MOT o mocy $100 \mathrm{kVA} / 80 \mathrm{~kW}$. Wyniki modelowania procesu spalania dla różnych nastaw kąta wtrysku paliwa porównano z wynikami uzyskanymi podczas indykowania silnika rzeczywistego. Analizę numeryczna wykonano w dwóch programach przeznaczonych do trójwymiarowego modelowania obiegu cieplnego tłokowego silnika spalinowego, a mianowicie AVL FIRE oraz KIVA-3V.
\end{abstract}

Słowa kluczowe: silnik spalinowy, modelowanie, spalanie

\section{Introduction}

Early models of the thermal cycle of the compression ignition engine appeared in the 20s of the last century. In 1926, Schweitzer published a model of heat release in the compression ignition engine [14]. In the $60 \mathrm{~s}$, the development of computation models followed $[11,16]$. Initially, those were single-zone models, and later on they were extended to multi-zone direct-injection models. Models for engines with a divided combustion chamber were then came into being [15]. Models based on the fuel injection characteristics were created. One of the first advanced multi-dimension combustion process models for engines with liquid fuel injection to the combustion chamber was the CONCHAS-SPRAY model developed at the Los Alamos Scientific Laboratory in the USA. Since the 70s, this model has been modified and complemented with a number of sub-models and has become a basis for creating the KIVA program. The KIVA-3V program [1 -3] enables modelling of flow processes, including combustion, fuel injection and heat exchange. This is an incomplete model requiring a number of input quantities for conducting computation. For the description of turbulence of the load, the k- $\varepsilon$ model and the initial swirl model with the capability to shape the initial fresh load profile were used. The program allows the three-dimensional engine working space to be modelled in either the cylindrical or Cartesian co-ordinate system. For modelling the fuel injection process, sub-models of fuel particle collisions and the size-reduction and coalescence fuel droplets and their evaporation are provided in the KIVA-3V program.

Many research centres around the world are involved in the modelling of the process of combustion in compression ignition engines. It is advanced computer programs that

\section{Wstęp}

Pierwsze modele obiegu cieplnego silnika o zapłonie samoczynnym pojawiały się w latach dwudziestych poprzedniego wieku. W roku 1926 Schweitzer opublikował model wywiązywania się ciepła w silniku wysokoprężnym [14]. W latach sześćdziesiątych nastąpił rozwój modeli obliczeniowych $[11,16]$. Były to modele początkowo jednostrefowe, a później rozszerzano je do modeli wielostrefowych z wtryskiem bezpośrednim. Powstały modele dla silników z dzieloną komorą spalania [15]. Tworzono modele oparte na charakterystyce wtrysku paliwa. Jednym z pierwszych zaawansowanych modeli wielowymiarowych procesu spalania dla silników z wtryskiem paliwa ciekłego do komory spalania był model CONCHAS-SPRAY, opracowany w Los Alamos Scientific Laboratory w USA. Od lat siedemdziesiątych XX w. model ten ulegał modyfikacjom oraz uzupełnianiu wieloma podmodelami i stał się bazą do stworzenia programu KIVA. Program KIVA-3V [1 - 3] pozwala modelować procesy przepływowe, włączając spalanie, wtrysk paliwa i wymianę ciepła. Jest to model niekompletny, wymagający wielu wartości wielkości wejściowych do prowadzenia obliczeń. Do opisu procesu turbulencji ładunku zastosowano model k- $\varepsilon$ oraz model wstępnego zawirowania świeżego ładunku z możliwością kształtowania jego początkowego profilu. Program ten pozwala na modelowanie trójwymiarowej przestrzeni roboczej silnika w układzie współrzędnych cylindrycznych lub prostokątnych. W programie KIVA-3V do modelowania procesu wtrysku paliwa stworzono podmodele zderzeń cząsteczek paliwa, rozdrobnienia i koalescencji kropel paliwa oraz ich odparowania.

Wiele ośrodków badawczych na całym świecie zajmuje się modelowaniem procesu spalania w silnikach z zapłonem 
are used for this purpose, which serve for solving flows in combustion engine chambers of any geometry by numerical methods. These are programs belonging to the fluid mechanics field, where numerical methods are employed for solving CFD (Computational Fluids Dynamics) problems.

Using the STAR-CD program, Gunabalan et al. [9] subjected the operation of a single-cylinder direct-injection compression ignition engine to numerical analysis. The examination included, among other things, the effect of the injection advance angle on the maximum pressure and temperature magnitudes and the emission of $\mathrm{NO}_{\mathrm{x}}$ and soot. The influence of exhaust gas recirculation (EGR) on the aforementioned engine operation parameters was also examined. The engine model ran at a constant speed of $1000 \mathrm{rpm}$, and the beginning of injection was set at $12^{\circ}$ (the base value), $16^{\circ}$ and $20^{\circ}$ CRA before TDC. The results of the analysis showed that the maximum pressure and temperature values occurred, of course, at the earliest moment of fuel injection to the combustion chamber, that is at $20^{\circ} \mathrm{CA}$ before TDC. A maximum pressure of $11.5 \mathrm{MPa}$ and a maximum temperature of $1197 \mathrm{~K}$ were obtained. For this setting of the injection angle, the highest $\mathrm{NO}_{\mathrm{x}}$ emission (approx. $40 \mathrm{~g} / \mathrm{kg}_{\text {fuel }}$ ) and, at the same time, the lowest combustion gas soot content (approx. $0.7 \mathrm{~g} / \mathrm{kg}_{\text {fuel }}$ ) were obtained, as compared to the remaining two settings. After introducing combustion gas in the amount of $20 \%$ to the fresh load, a decrease in combustion gas $\mathrm{NO}_{\mathrm{x}}$ content by approx. $50 \%$, but an increase in soot emission by approx. $70 \%$ were obtained. The combination of an injection advance of $20^{\circ} \mathrm{CA}$ before TDC with $10 \%$ EGR proved to be a setting optimal in terms of the emission.

Work [6] reports the results of modelling fuel mixture formation and combustion in the turbocharged direct injection compression ignition engine by Caterpillar. The numerical analysis was performed using the FIRE program. The 2440 $\mathrm{cm} 3$ displacement engine model operated at rotational speed equal to $1600 \mathrm{rpm}$ and with an injection start angle of $9^{\circ} \mathrm{CA}$ before TDC. As a result of computations, cylinder pressure variations and the curves of $\mathrm{NO}_{x}$ and soot formation in the engine exhaust gas were obtained; these results were then compared with the result of research work carried out on the real engine. As a result, fairly good agreement between the modelling results and experimental test results were achieved; and what the engine model reflected best was the variation of pressure in the engine.

In their work [12]. Kusakai Daisho reported the results of modelling the combustion and exhaust gas emission processes in the CI turbocharged engine with the common-rail system. The numerical analysis was performed using the KIVA-3V program, as modified by being supplemented with chemical reaction sub-models taken from the CHEMKINII program. The object of investigation was a six-cylinder turbocharged CI engine of a total displacement of $7790 \mathrm{~cm}^{3}$. The most important findings derived from the modelling are as follows:

a) in the first phase, the injected fuel undergoing lowtemperature reactions decomposes into $\mathrm{HCHO}$ and $\mathrm{CO}$ samoczynnym. Wykorzystywane do tego celu są właśnie zaawansowane programy komputerowe, służące do rozwiązywania metodami numerycznymi przepływów w komorach silników spalinowych o dowolnej geometrii. Są to programy należące do działu mechaniki płynów, wykorzystującego metody numeryczne do rozwiązywania zagadnień przepływu płynów - CFD (Computational Fluids Dynamics).

Gunabalan i inni [9], wykorzystując program STAR$\mathrm{CD}$, poddali analizie numerycznej pracę jednocylindrowego silnika o zapłonie samoczynnym z wtryskiem bezpośrednim. Zbadano m.in. wpływ kąta wyprzedzenia wtrysku na maksymalną wartość ciśnienia i temperatury oraz na emisję $\mathrm{NO}_{\mathrm{x}}$ i sadzy. Poddano również analizie wpływ recyrkulacji spalin (EGR) na wymienione parametry pracy silnika. Model silnika pracował ze stałą prędkością równą $1000 \mathrm{obr} / \mathrm{min}$, a początek wtrysku ustalono na $12^{\circ}$ (wartość bazowa), $16^{\circ}$ oraz $20^{\circ}$ OWK przed GMP. Wyniki analizy pokazały, iż maksymalna wartość ciśnienia i temperatury występuje przy najwcześniejszej chwili wtrysku paliwa do komory spalania $-20^{\circ} \mathrm{OWK}$ przed GMP. Otrzymano odpowiednio ciśnienie maksymalne równe 11,5 MPa oraz temperaturę maksymalną $1197 \mathrm{~K}$. Dla tej nastawy kąta wtrysku otrzymano najwyższą emisję NOx (ok. $40 \mathrm{~g} / \mathrm{kg}_{\text {paliwa }}$ ) i jednocześnie najmniejszą zawartość sadzy w spalinach (ok. $0,7 \mathrm{~g} / \mathrm{kg}_{\text {paliwa }}$ ), w porównaniu do dwóch pozostałych ustawień. Po wprowadzeniu spalin do świeżego ładunku w wysokości $20 \%$ otrzymano spadek zawartości $\mathrm{NO}_{\mathrm{x}} \mathrm{w}$ spalinach o ok. 50\%, ale wzrost emisji sadzy o ok. $70 \%$. Najbardziej optymalną pod względem emisji nastawą okazała się kombinacja kąta wyprzedzenia wtrysku o wartości $20^{\circ}$ OWK przed GMP oraz $10 \%$ EGR.

W pracy [6] przedstawiono wyniki modelowania tworzenia mieszanki i spalania w doładowanym silniku wysokoprężnym o wtrysku bezpośrednim firmy Caterpillar. Analizę numeryczną wykonano przy użyciu programu FIRE. Model silnika o pojemności skokowej $2440 \mathrm{~cm}^{3}$ pracował z prędkością obrotową równą $1600 \mathrm{obr} / \mathrm{min}$ i przy kącie początku wtrysku $9^{\circ} \mathrm{OWK}$ przed GMP. W wyniku obliczeń otrzymano przebiegi ciśnienia w cylindrze, krzywe tworzenia się $\mathrm{NO}_{\mathrm{x}}$ oraz sadzy w spalinach silnika; wyniki te porównano z wynikami prac badawczych prowadzonych na rzeczywistym silniku. W efekcie otrzymano dość dobrą zgodność wyników modelowania z wynikami prac eksperymentalnych, a najlepiej model silnika odzwierciedlił przebieg ciśnienia $\mathrm{w}$ cylindrze.

Kusaka i Daisho w swej pracy [12] przedstawili wyniki modelowania procesu spalania i emisji spalin w doładowanym silniku o ZS, z systemem common-rail. Analizę numeryczną wykonano z zastosowaniem programu KIVA-3V, zmodyfikowanego o podmodele reakcji chemicznych z programu CHEMKIN-II. Obiektem badań był sześciocylindrowy, doładowany silnik o ZS o pojemności całkowitej 7790 $\mathrm{cm}^{3}$. Najważniejsze wnioski wypływające z modelowania: a) w pierwszej fazie wtryśnięte paliwo, pod wpływem reakcji niskotemperaturowych, rozkłada się na $\mathrm{HCHO}$ i CO, następnie w reakcjach wysokotemperaturowych powstaje $\mathrm{OH}$ i $\mathrm{CO}_{2}$, 
and then, as a result of high-temperature reactions, $\mathrm{OH}$ and $\mathrm{CO}_{2}$ are formed;

b) NO forms immediately around the fuel-rich regions after approx. $376^{\circ} \mathrm{CA}$ and diffuses into the combustion chamber. The formed $\mathrm{NO}$ partially converts to $\mathrm{NO}_{2}$ in external regions.

The numerical analysis results were compared with the results of experimental tests. Good consistence, both qualitative and quantitative, was obtained for pressure variation in the cylinder, the heat release degree and the NO contents of exhaust gas. Whereas, considerable discrepancy was obtained between the results for soot formation in the exhaust gas. The modelling yielded an exhaust gas soot concentration being ten times that obtained in reality. It was determined that more detailed exhaust gas soot formation reactions were required to be used in further studies.

In all of the cases discussed above, a turbulence model used for computation was the $\mathrm{k}-\varepsilon$ model, while for determining the NO emission an extended thermal model, as proposed by Zeldovich, was employed.

In the Institute of Internal Combustion Machines and Control Engineering of the Czestochowa University of Technology, aside from the KIVA-3V program, the FIRE program has also been in use for more than a year, which was made available by the AVL company within the University Partnership Program. The FIRE program [4], being one of the state-of-the-art and, at the same time, intensively developed computer programs, is used for modelling the thermal cycle of an internal combustion engine. The FIRE program enabled the computation of transfer, mixing, ignition and turbulent combustion phenomena occurring in a piston engine. The combustion of both heterogeneous and homogeneous mixtures formed by the injection of liquid fuel to the chamber can be modelled. Computation can apply both to a spark-ignition engine and to a self-ignition engine. The self-ignition process can be carried out using several knock-combustion sub-models (AnB Knock, Shell Model, and others). The load turbulence model can be modelled using either the $\mathrm{k}-\varepsilon$ model, or the more modern k-zeta-f model [4].

\section{The object of investigation}

Modelling of the thermal cycle of a self-ignition piston engine in the AVL FIRE and KIVA-3V programs was carried out within the study. The object of investigation was a 6CT107 turbocharged self-ignition internal combustion engine fed with diesel oil (Fig. 1), installed on an ANDORIAMOT $100 \mathrm{kVA} / 80 \mathrm{~kW}$ power generating set in a portable version.

Engine specification:
a) CI 6-cylinder engine, supercharged,
b) displacement: $\quad 6.54 \mathrm{dm}^{3}$
c) rotational speed: $\quad 1500 \mathrm{rpm}$
d) crank throw:
$60.325 \mathrm{~mm}$
e) cylinder bore:
$107.19 \mathrm{~mm}$
f) connecting-rod length: $245 \mathrm{~mm}$
g) compression ratio: $\quad 16.5$.

b) NO tworzy się natychmiast wokół obszarów bogatych w paliwo po ok. $376^{\circ} \mathrm{OWK}$ i dyfunduje w głąb komory spalania. Powstałe NO, w zewnętrznych obszarach, częściowo konwertuje na $\mathrm{NO}_{2}$.

Wyniki analizy numerycznej porównano z wynikami badań eksperymentalnych. Otrzymano dobrą zgodność zarówno jakościową, jak i ilościową, w odniesieniu do przebiegu ciśnienia w cylindrze, stopnia wydzielania ciepła i zawartości NO w spalinach. Natomiast znaczne rozbieżności otrzymano dla wyników tworzenia się sadzy w spalinach. Podczas modelowania uzyskano dziesięciokrotnie większe wartości koncentracji sadzy w spalinach niż w rzeczywistości. Stwierdzono, iż w dalszych badaniach należy zastosować bardziej szczegółowe reakcje tworzenia się sadzy w spalinach.

We wszystkich omawianych powyżej przypadkach modelem turbulencji jaki zastosowano do obliczeń był model $\mathrm{k}-\varepsilon$, natomiast do wyznaczenia emisji NO wykorzystywano rozszerzony, termiczny mechanizm Zeldowicza.

W Instytucie Maszyn Tłokowych i Techniki Sterowania Politechniki Częstochowskiej do modelowania obiegu cieplnego silnika tłokowego obok programu KIVA-3V od ponad roku wykorzystywany jest także program FIRE, udostępniony przez firmę AVL w ramach University Partnership Program. Program FIRE [4] należy do najnowocześniejszych i jednocześnie intensywnie rozwijanych programów komputerowych wykorzystywanych do modelowania obiegu cieplnego tłokowego silnika spalinowego. Program FIRE umożliwia obliczanie zjawisk transportu, mieszania, zapłonu i turbulentnego spalania w silniku tłokowym. Modelować można spalanie zarówno mieszanek homogenicznych, jak i mieszanek heterogenicznych utworzonych przez wtrysk paliwa ciekłego do komory. Obliczenia mogą dotyczyć zarówno silnika o zapłonie iskrowym, jak i silnika o zapłonie samoczynnym. Proces samozapłonu może być realizowany z wykorzystaniem kilku podmodeli spalania stukowego (AnB Knock, Shell Model i inne). Proces turbulencji ładunku może być modelowany z wykorzystaniem modelu k- $\varepsilon$ oraz za pomocą nowocześniejszego modelu k-zeta-f [4].

\section{Obiekt badań}

W ramach pracy przeprowadzono modelowanie obiegu cieplnego tłokowego silnika o zapłonie samoczynnym w programie AVL FIRE i KIVA-3V. Obiektem badań był doładowany silnik spalinowy o zapłonie samoczynnym 6CT107 zasilany olejem napędowym (rys. 1), zainstalowany na agregacie prądotwórczym firmy ANDORIA-MOT o mocy 100 kVA/80 kW w wersji przewoźnej.

Dane silnika:

a) silnik o ZS sześciocylindrowy, doładowany

b) pojemność skokowa $\quad 6,54 \mathrm{dm}^{3}$

c) prędkość obrotowa $\quad 15001 / \mathrm{min}$

d) promień wykorbienia $\quad 60,325 \mathrm{~mm}$

e) średnica cylindra $\quad 107,19 \mathrm{~mm}$

f) długość korbowodu $245 \mathrm{~mm}$

g) stopień sprężania $\quad 16,5$. 

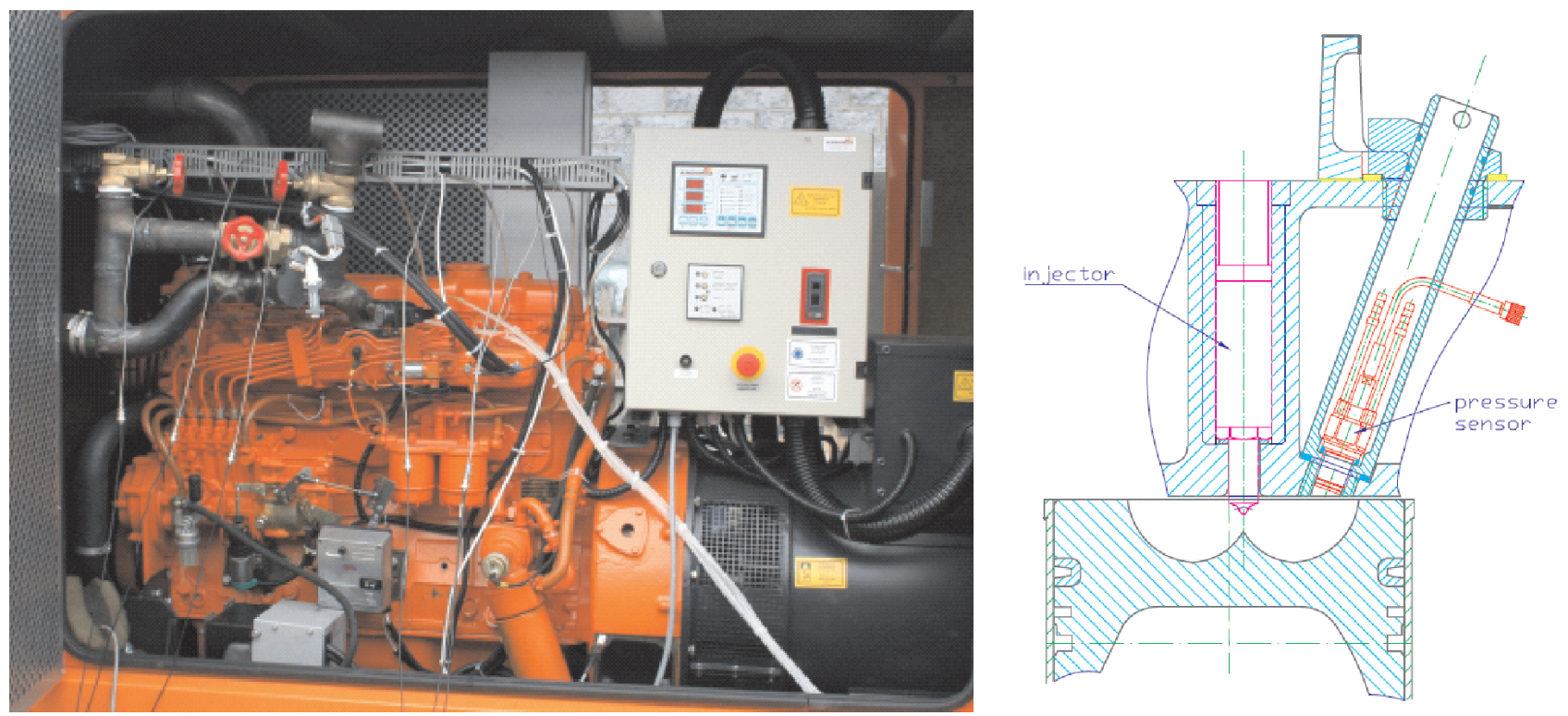

Fig. 1. The 6CT107 test internal combustion engine

Rys. 1. Badawczy silnik spalinowy 6 CT107

\section{Description of the ECFM-3Z combustion model of the AVL FIRE program}

The ECFM (Extended Coherent Flame Model) model [7] was developed specially for modelling the combustion process in a compression ignition engine. The CFM has been successfully used for modelling the process of combustion in spark ignition engines. The ECFM-3Z model belongs to a group of advanced models of the combustion process in a compression ignition engine. For several years it has been successfully used, constantly modified and improved by many researchers [19]. Together with turbulence process submodels (e.g. the k-zeta-f), exhaust gas component formation, knock combustion and other sub-models, they constitute a useful tool for modelling and analysis of the thermal cycle of the compression ignition internal combustion engine.

To adapt the model for the modelling of the combustion process in the self-ignition engine, a sub-model has been added, which describes the process of mixing fuel to be injected to the combustion chamber. The turbulent combustion process is defined by the time scale of chemical reactions, the time scale of turbulent processes, and turbulence intensity. The flame front is formed by the turbulent effect of load vortices and interaction between the burned zone and the unburned part of the load. The time scale of chemical processes is much smaller than that defining the load turbulence. This model is based on the concept of laminar flame propagation with flame velocity and flame front thickness as the average flame front values. It is also assumed that the reactions occur in a relatively thin layer separating unburned gases from the completely burned gases [4]. The model relies on the flame front transfer equation, as well as on the mixing model describing the combustion of an inhomogeneous mix and the diffusion combustion model. The model assumes the division of the combustion region into three zones (Fig. 2): a sole fuel zone, a zone of sole air with a possible presence

\section{Charakterystyka modelu spalania ECFM-3Z programu AVL FIRE}

Model ECFM (Extended Coherent Flame Model) [7] został opracowany specjalnie do modelowania procesu spalania w silniku o zapłonie samoczynnym. Model spalania CFM był z powodzeniem stosowany do modelowania spalania $\mathrm{w}$ silnikach o zapłonie iskrowym. Model ECFM-3Z należy do grupy zaawansowanych modeli procesu spalania w silniku o zapłonie samoczynnym. Od kilku lat jest wykorzystywany, ciągle modyfikowany i udoskonalany przez wielu badaczy [19]. Wraz z podmodelami procesu turbulencji (np. k-zeta-f), podmodelami tworzenia się toksycznych składników spalin, spalania stukowego i innymi tworzą użyteczne narzędzia do modelowania i analizy obiegu cieplnego tłokowego silnika spalinowego o zapłonie samoczynnym.

W celu przystosowania modelu do modelowania procesu spalania w silniku o zapłonie samoczynnym dodano podmodel opisujący proces mieszania wtryskiwanego paliwa do komory spalania. Proces spalania turbulentnego jest określony przez skalę czasową reakcji chemicznych, skalę czasową procesów turbulentnych oraz intensywność turbulencji. Front płomienia jest formowany przez oddziaływanie turbulentne wirów ładunku oraz przez wzajemne oddziaływanie strefy spalonej i niespalonej części ładunku. Skala czasowa procesów chemicznych jest dużo mniejsza niż skala czasowa określająca turbulencję ładunku. Model ten oparty jest na koncepcji rozprzestrzeniania się płomienia laminarnego o prędkości oraz grubości frontu płomienia jako wartościach średnich frontu płomienia. Zakłada się także, że reakcje zachodzą w relatywnie cienkiej warstwie oddzielającej gazy niespalone od całkowicie spalonych [4]. Model ten bazuje na równaniu transportu frontu płomienia oraz modelu mieszania opisującego spalanie mieszanki niehomogenicznej oraz spalania dyfuzyjnego. W modelu założono podział obszaru spalania na trzy strefy (rys. 2): 
of exhaust gases remained from the previous engine operation cycle, and an air-fuel mixture zone, where combustion reactions occur following the ECFM concept. The air-fuel mixture formation model provides for gradual mixing of fuel with air. The created combustion model is called ECFM-3Z (3-Zones Extended Coherent Flame Model). In this model, the mixture zone is additionally divided into a burned and an unburned zone. To initiate the combustion process, the self-ignition model for the forming mixture zone and for the diffusion flame zone is used [7]. The ECFM makes use of the 2-stage fuel oxidation mechanism $\left(\mathrm{C}_{13} \mathrm{H}_{23}\right)$ [4]:

$$
\begin{gathered}
\mathrm{C}_{\mathrm{n}} \mathrm{H}_{\mathrm{m}} \mathrm{O}_{\mathrm{k}}+\left(\mathrm{n}+\frac{\mathrm{m}}{4}-\frac{\mathrm{k}}{2}\right) \mathrm{O}_{2} \rightarrow \mathrm{nCO}_{2}+\frac{\mathrm{m}}{2} \mathrm{H}_{2} \mathrm{O} \\
\mathrm{C}_{\mathrm{n}} \mathrm{H}_{\mathrm{m}} \mathrm{O}_{\mathrm{k}}+\left(\frac{\mathrm{n}}{2}-\frac{\mathrm{k}}{2}\right) \mathrm{O}_{2} \rightarrow \mathrm{nCO}+\frac{\mathrm{m}}{2} \mathrm{H}_{2}
\end{gathered}
$$

where: $n, m, k$ - number of the atoms of carbon, hydrogen and oxygen in the fuel, respectively.

$$
\begin{gathered}
\mathrm{C}_{13} \mathrm{H}_{23}+18.75 \mathrm{O}_{2} \rightarrow 13 \mathrm{CO}_{2}+11.5 \mathrm{H}_{2} \mathrm{O} \\
\mathrm{C}_{13} \mathrm{H}_{23}+11.5 \mathrm{O}_{2} \rightarrow 13 \mathrm{CO}+11.5 \mathrm{H}_{2}
\end{gathered}
$$

The reaction of formation of $\mathrm{CO}$ and $\mathrm{H}_{2}$ is taken into account for stoichiometric and fuel-rich mixtures, while for lean mixtures this reaction is omitted.

In the ECFM-3Z model, transport equations for the chemical components $\mathrm{O}_{2}, \mathrm{~N}_{2}, \mathrm{CO}_{2}, \mathrm{CO}, \mathrm{H}_{2}, \mathrm{H}_{2} \mathrm{O}, \mathrm{O}, \mathrm{H}, \mathrm{N}$, $\mathrm{OH}$ and $\mathrm{NO}$ are also solved.

The term "burned gases" means the actual combustion products of the mixture zone (the zone $\mathrm{M}^{\mathrm{b}}$, Fig. 2) and the part of the fuel that has not been mixed with air and has not been burned (the zone $\mathrm{F}^{\mathrm{b}}$, Fig. 2$)$, and the air (( $\mathrm{A}^{\mathrm{b}}$, Fig. 2$)$. The fuel is divided into two parts: the fuel present in the fresh load part prior to being combusted, $\widetilde{y}_{\mathrm{Fu}}^{\mathrm{u}}$, and the fuel present in the exhaust gas, $\widetilde{\mathrm{y}}_{\mathrm{Fu}}^{\mathrm{b}}$ [4]. For the calculation of $\widetilde{y}_{\mathrm{Fu}}^{\mathrm{u}}$, the transport equation is used [4].

The concept of the injected fuel and air mixing model relies on the characteristic time-scale of the turbulence model. Because of the occurring process of fuel evaporation, it is necessary to determine the amount of fuel entering the mixture zone (from the zone to the zone $\left(\mathrm{M}=\mathrm{M}^{\mathrm{u}}+\mathrm{M}^{\mathrm{b}}\right.$, Fig. 2) and to the pure fuel zone ( $F=F^{u}+F^{b}$, Fig. 2). In the injected fuel stream, fuel droplets are situated so close to one another as to form altogether a sole fuel zone. After the fuel has evaporated, a specific time is still needed for mixing of the pure fuel zone fuel (F) with air (A) and formation of the combustible mixture (M). To determine the three mixture zones, relationships are defined for the zone of fuel unmixed with air:

$$
\widetilde{y}_{\mathrm{Fu}}^{\mathrm{F}}=\widetilde{\mathrm{y}}_{\mathrm{Fu}}^{\mathrm{u}, \mathrm{F}}+\widetilde{\mathrm{y}}_{\mathrm{Fu}}^{\mathrm{b}, \mathrm{F}}
$$

and for the zone of air remaining outside the mixture: samego paliwa, samego powietrza z możliwą obecnością pozostałych gazów spalinowych z poprzedniego cyklu pracy silnika oraz strefa mieszanki paliwowo-powietrznej, w której zachodzą reakcje spalania według koncepcji modelu ECFM. Model tworzenia mieszanki palnej polega na stopniowym mieszaniu się paliwa z powietrzem. Powstały model spalania został nazwany ECFM-3Z (3-Zones Extended Coherent Flame Model). W modelu tym strefa mieszanki dodatkowo podzielona jest na strefę spaloną i niespaloną. Do zainicjowania procesu spalania jest wykorzystywany model samozapłonu dla strefy tworzącej się mieszanki oraz dla strefy płomienia dyfuzyjnego [7]. W modelu ECFM wykorzystany jest 2-stopniowy mechanizm utleniania paliwa $\left(\mathrm{C}_{13} \mathrm{H}_{23}\right)$ [4] - wzory (1), (2), gdzie: n, m, k - liczba atomów węgla, wodoru i tlenu w paliwie oraz wzory (3) i (4).

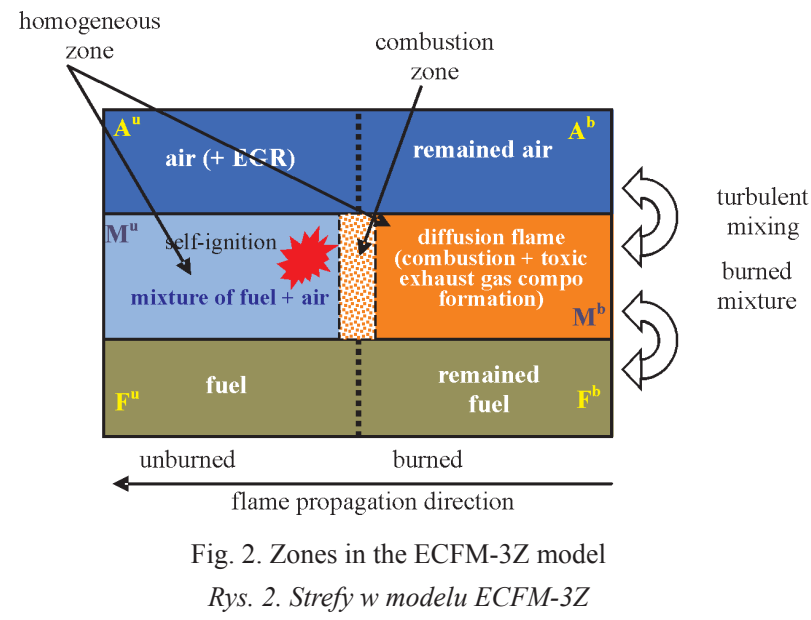

Reakcja powstawania $\mathrm{CO}$ oraz $\mathrm{H}_{2}$ jest brana pod uwagę dla mieszanek stechiometrycznych oraz bogatych w paliwo, natomiast dla mieszanek ubogich reakcja ta jest pomijana.

W modelu ECFM-3Z rozwiązywane są także równania transportu dla składników chemicznych: $\mathrm{O}_{2}, \mathrm{~N}_{2}, \mathrm{CO}_{2}, \mathrm{CO}$, $\mathrm{H}_{2}, \mathrm{H}_{2} \mathrm{O}, \mathrm{O}, \mathrm{H}, \mathrm{N}, \mathrm{OH}$ oraz NO.

Pod pojęciem „spalone gazy” rozumie się rzeczywiste produkty spalania strefy mieszanki (strefa $\mathrm{M}^{\mathrm{b}}$, rys. 2) i część paliwa, która nie uległa wymieszaniu się z powietrzem i nie uległa spaleniu (strefa $\mathrm{F}^{\mathrm{b}}$, rys. 2 ) oraz powietrze $\left(\mathrm{A}^{\mathrm{b}}\right.$, rys. 2). Paliwo jest podzielone na dwie części: paliwo obecne $w$ części świeżego ładunku przed spaleniem $\widetilde{y}_{\mathrm{Fu}}^{\mathrm{u}}$ oraz paliwo obecne w spalinach $\widetilde{y}_{\mathrm{Fu}}^{\mathrm{b}}$ [4]. Do obliczania $\widetilde{\mathrm{y}}_{\mathrm{Fu}}^{\mathrm{u}}$ wykorzystywane jest równanie transportu [4].

Koncepcja modelu mieszania wtryśniętego paliwa $\mathrm{z}$ powietrzem oparta jest na charakterystycznej skali czasowej modelu turbulencji. Ze względu na zachodzący proces odparowania paliwa konieczne jest określenie ilości paliwa wchodzącego do strefy mieszanki (ze strefy F do strefy $\mathrm{M}=\mathrm{M}^{\mathrm{u}}+\mathrm{M}^{\mathrm{b}}$, rys. 2$)$ oraz do strefy czystego paliwa $(\mathrm{F}=$ $=\mathrm{F}^{\mathrm{u}}+\mathrm{F}^{\mathrm{b}}$, rys. 2). W strudze wtryskiwanego paliwa krople paliwa znajdują się tak blisko siebie, że tworzą strefę samego paliwa. Po odparowaniu paliwa nadal wymagany jest określony czas do wymieszania się paliwa ze strefy czystego paliwa (F) z powietrzem (A) i wytworzenie palnej 


$$
\widetilde{\mathrm{y}}_{\mathrm{O}_{2}}^{\mathrm{A}}=\widetilde{\mathrm{y}}_{\mathrm{O}_{2}}^{\mathrm{u}, \mathrm{A}}+\widetilde{\mathrm{y}}_{\mathrm{O}_{2}}^{\mathrm{b}, \mathrm{A}}
$$

It is additionally assumed that the composition of gas, fuel + EGR is identical both in the mixture zone and in the zone being still unmixed. The mixture self-ignition delay is calculated from the empirical correlation [13]:

The combustion model for the self-ignition engine has been complemented with the unburned product zone. The exhaust gas contains unburned fuel and $\mathrm{O}_{2}, \mathrm{~N}_{2}, \mathrm{CO}_{2}, \mathrm{H}_{2} \mathrm{O}$, $\mathrm{H}_{2}$, NO, CO. The fuel oxidation occurs in two stages:

a) the first oxidation stage leads to the formation of large amounts of $\mathrm{CO}$ and $\mathrm{CO}_{2}$ in the exhaust gas of the mixture zone,

b) at the second stage in the mixture zone exhaust gas, the previously formed $\mathrm{CO}$ is oxidized to $\mathrm{CO}_{2}$.

\section{Description of the combustion model in the KIVA-3V program}

The KIVA-3V enables the computation of three-dimensional flows in engine chambers of an arbitrary geometry, including the turbulence effects and heat exchange with the walls. The KIVA-3V is an example of the three-dimensional field model in which the combustion process (the mode and velocity of flame from propagation) is the result of solving the basic conservation equations and their complementary relationships that define the flow field in the front area, the course of the chemical reactions of combustion and the momentary thermodynamic state of the medium [1 -3$]$. The model relies on solving the equations of conservation of mass, momentum, energy and the quantities of components, which describe the nonstationary field of flow with a chemical reaction (combustion). These equations are three-dimensional Navier-Stokes equations for a mixture of compressive fluids. The sub-model of the chemical reactions of the hydrocarbon fuel combustion process considers four kinetic reactions and six equilibrium reactions. The first kinetic reaction defines the oxidation of fuel. The next three reactions describe the nitrogen oxide formation mechanism, following Zeldowicz's model. The turbulence process can be modelled using one of the three sub-models: the SGS (Sub-Grid Scale), the k- $\varepsilon$ or the RNG k- $\varepsilon$ (ReNormalisation Group). For modelling turbulence in the present study, the $\mathrm{k}-\varepsilon$ model was used, in which the kinematic viscosity, $\mu_{\mathrm{t}}$, is dependent on the kinetic energy of turbulence, $\mathrm{k}$, and on the turbulence kinetic energy dissipation rate, $\varepsilon$.

\section{Modelling results}

The same computational grids were used for both computer programs (Fig. 3). Computations were conducted for the angle range from $-180^{\circ} \mathrm{CA}$ before $\mathrm{TDC}$ to $180^{\circ} \mathrm{CA}$ after TDC.

The grid of the modelled combustion chamber of the 6CT107 test engine consisted of nearly 36000 computation cells. Two-layered wall boundary layer was considered.

Figures 4 and 5 show the variation of combustion pressures obtained as a result of indicating the real test engine and mod- mieszanki (M). W celu określenia trzech stref mieszanki zdefiniowano zależność dla strefy paliwa niewymieszanego z powietrzem (5) oraz dla strefy powietrza pozostającego poza mieszanką (6).

Dodatkowo zakłada się, że skład gazu, powietrze + EGR, jest taki sam zarówno w strefie mieszanki, jak i w strefie jeszcze niewymieszanej. Opóźnienie samozapłonu mieszanki obliczane jest z korelacji empirycznej [13].

Model spalania dla silnika o zapłonie samoczynnym został uzupełniony o strefę niespalonych produktów. W spalinach znajduje się niespalone paliwo oraz $\mathrm{O}_{2}, \mathrm{~N}_{2}, \mathrm{CO}_{2}$, $\mathrm{H}_{2} \mathrm{O}, \mathrm{H}_{2}, \mathrm{NO}, \mathrm{CO}$. Utlenianie paliwa zachodzi w dwóch etapach:

1) prowadzi do powstania dużej ilości $\mathrm{CO}$ oraz $\mathrm{CO}_{2}$, w gazach spalinowych strefy mieszanki,

2) w gazach spalinowych strefy mieszanki poprzednio powstały $\mathrm{CO}$ jest utleniany do $\mathrm{CO}_{2}$.

\section{Charakterystyka modelu spalania $w$ programie KIVA-3V}

KIVA-3V pozwala on na obliczanie przepływów trójwymiarowych w komorach silników o dowolnej geometrii, włączając efekty turbulencji i wymianę ciepła ze ściankami. KIVA-3V jest przykładem trójwymiarowego modelu polowego, w którym przebieg procesu spalania (sposób i prędkość rozprzestrzeniania się frontu płomienia) jest wynikiem rozwiązywania podstawowych równań zachowania oraz uzupełniających je zależności, które określają pole przepływu w rejonie frontu, przebieg reakcji chemicznych spalania oraz chwilowy stan termodynamiczny czynnika [1 - 3]. Model bazuje na rozwiązywaniu równań zachowania masy, pędu, energii i ilości składników, opisujących nieustalone, trójwymiarowe pole przepływu z reakcją chemiczną (spalaniem). Równania te to trójwymiarowe równania Naviera-Stokesa dla mieszaniny płynów ściśliwych. W podmodelu reakcji chemicznych procesu spalania paliwa węglowodorowego uwzględniono cztery reakcje kinetyczne i sześć reakcji równowagowych. Pierwsza reakcja kinetyczna określa utlenianie paliwa. Kolejne trzy opisują, zgodnie z rozszerzonym modelem Zeldowicza, mechanizm tworzenia tlenku azotu. Proces turbulencji może być modelowany przy użyciu jednego z trzech podmodeli: SGS (Sub-Grid Scale), k- $\varepsilon$ lub RNG k- $\varepsilon$ (ReNormalisation Group). W pracy do modelowania turbulencji wykorzystano model k- $\varepsilon$, w którym lepkość kinematyczna $\mu_{\mathrm{t}}$ uzależniona została od energii kinetycznej turbulencji k i od szybkości dyssypacji energii kinetycznej turbulencji $\varepsilon$.

\section{Wyniki modelowania}

Dla obydwu programów komputerowych wykorzystano takie same siatki obliczeniowe (rys. 3). Obliczenia prowadzono dla zakresu kątowego $-180^{\circ} \mathrm{OWK}$ przed GMP do $180^{\circ}$ OWK po GMP.

Siatka modelowanej komory spalania silnika badawczego 6CT107 składała się z prawie 36000 komórek obliczeniowych. Uwzględniono 2-warstwową warstwę przyścienną. Parametry modelowania podano $\mathrm{w}$ tabeli 1 .

Na rysunkach 4 i 5 przedstawiono przebieg ciśnienia spalania uzyskany w wyniku indykowania rzeczywistego 
elling with the KIVA-3V and AVL FIRE programs, respectively, for the same initial conditions and settings of fuel injection.

Figure 6 shows differences in pressure obtained using the KIVA-3V and the FIRE programs, respectively, compared to the pressure obtained by indicating the real

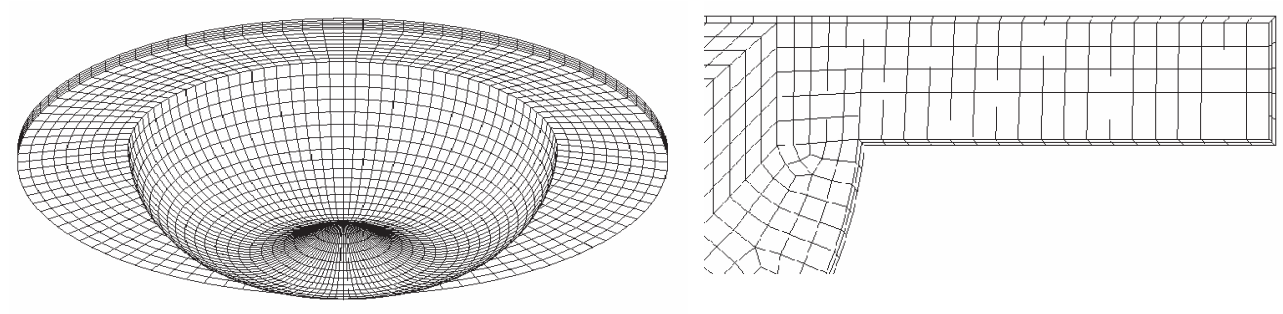

Fig. 3. The computational grid for combustion chamber modelling Rys. 3. Siatka obliczeniowa modelowanej komory spalania

Table 1. Modelling parameters

Tabela 1. Parametry modelowania

\begin{tabular}{|c|c|}
\hline Engine rotational speeds/prędkość obrotowa silnika & - $\quad 1500 \mathrm{rpm} / \mathrm{obr} / \mathrm{min}$ \\
\hline Cylinder bore/średnica cylindra & $-\quad 107.19 \mathrm{~mm}$ \\
\hline Crank throw/promień wykorbienia & $-60.325 \mathrm{~mm}$ \\
\hline Connecting-rod length/dtugość korbowodu & $-\quad 245 \mathrm{~mm}$ \\
\hline Initial pressure for $180^{\circ} \mathrm{CRA}$ before TDC/ciśnienie początkowe dla $180^{\circ} \mathrm{OWK}$ przed GMP & $-\quad 0.16 \mathrm{MPa}$ \\
\hline Initial temperature for $180^{\circ} \mathrm{CRA}$ before TDC/temp. poczatkowa dla $180^{\circ} \mathrm{OWK}$ przed GMP & $-310 \mathrm{~K}$ \\
\hline Injection angle/kąt wtrysku & $-\quad-9^{\circ} \mathrm{CA}$ before TDC \\
\hline Injected fuel mass/masa wtryskiwanego paliwa & $-\quad 0.0735 \mathrm{~g} /$ cycle \\
\hline Injection duration angle/kąt trwania wtrysku & $-\quad 20^{\circ} \mathrm{CRA}$ \\
\hline Fuel temperature/temp. paliwa & $-330 \mathrm{~K}$ \\
\hline \multicolumn{2}{|l|}{ FIRE program's sub-models/podmodele programu FIRE } \\
\hline Turbulence model/model turbulencji & - k-zeta-f \\
\hline Combustion model/model spalania & - $\quad$ Coherent Flame ECFM-3Z Model \\
\hline NO formation model/model tworzenia $N O$ & - $\quad$ extended Zeldowicz's model/rozszerzony \\
\hline Soot formation model/model tworzenia sadzy & - $\quad$ Lund Flamelet Model \\
\hline
\end{tabular}

engine. The results obtained with the FIRE program reflect the pressure variation of the real engine with greater accuracy. The maximum combustion pressure difference obtained with the KIVA-3V program amounted to $1.24 \mathrm{MPa}$ and occurred at $25^{\circ}$ CA after TDC. For the FIRE program, the combustion pressure difference was $0.12 \mathrm{MPa}$ and occurred at $26^{\circ} \mathrm{CA}$ after TDC.
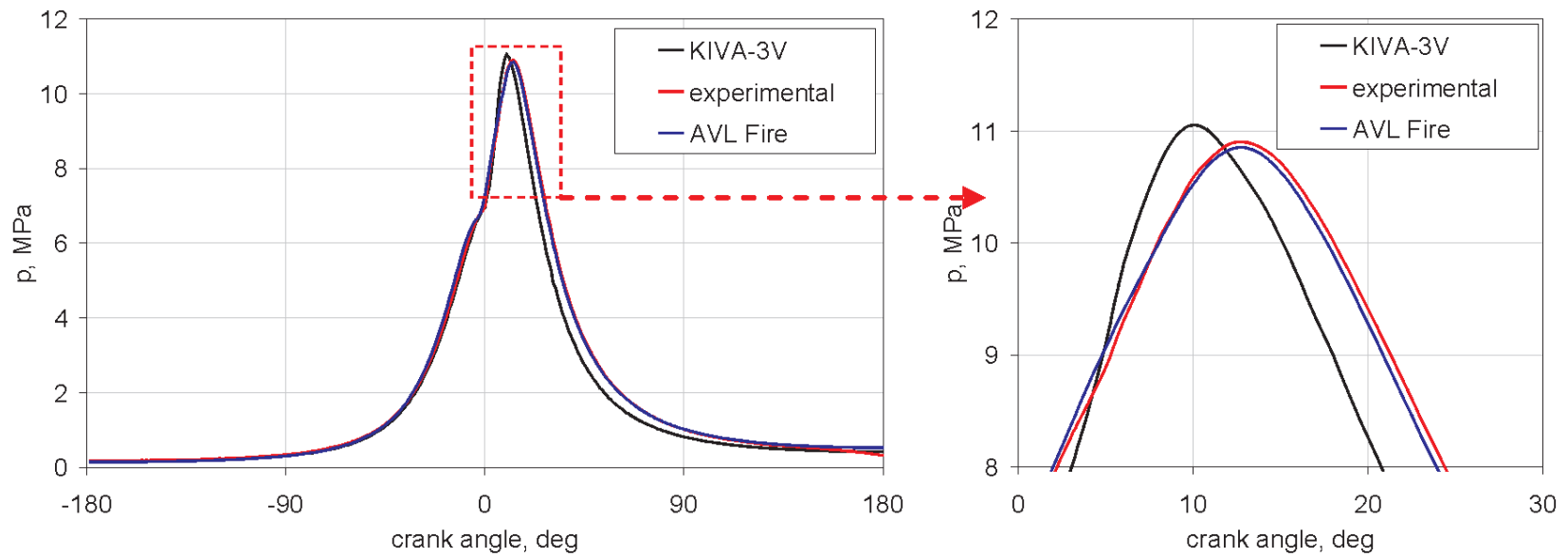

Fig. 4. Variation of combustion pressure in the real engine, as obtained by modelling with the KIVA-3V and the AVL FIRE programs, respectively Rys. 4. Przebieg ciśnienia spalania w silniku rzeczywistym, uzyskany modelowaniem programem KIVA-3V oraz programem AVL FIRE 


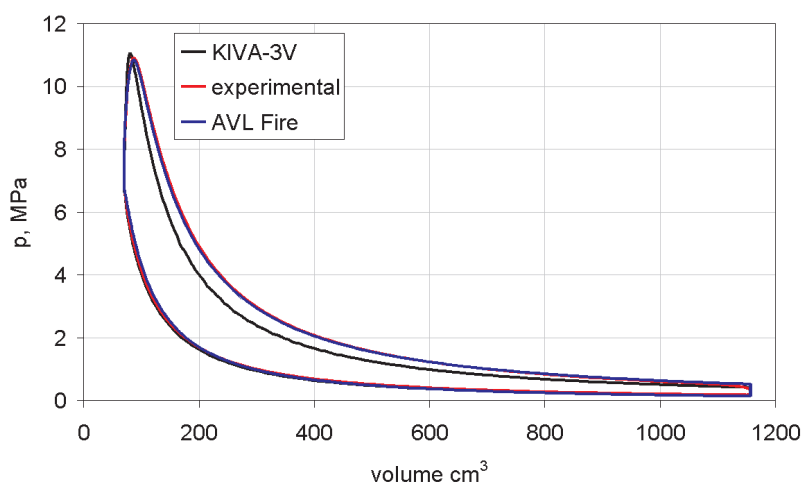

Fig. 5. Combustion pressure diagram in the p-V system Rys. 5. Wykres ciśnienia spalania w uktadzie $p-V$

Figure 7 shows the computed combustion pressure increment, respectively, for the real engine and for the models. From the pressure increment diagram it can be found that the $d p / d \alpha$ graph obtained with the FIRE program is closer to the performance of the real engine.

Figure 8 presents the obtained differences in $\mathrm{dp} / \mathrm{d} \alpha$ between modelling and indicating the real engine. For modelling with the FIRE program, the maximal difference in $\mathrm{dp} / \mathrm{d} \alpha$ was $0.14 \mathrm{MPa}$ at $1^{\circ} \mathrm{CA}$ after TDC, while that obtained with the KIVA-3V program was $0.3 \mathrm{MPa}$ at $11^{\circ} \mathrm{CA}$ after TDC.

In Figure 9, the computed values of mean indicated pressure are compared for the real engine and the model. A definite difference in pi was obtained from modelling with the KIVA-3V program. The difference against the real engine was $0.37 \mathrm{MPa}$. For modelling with the FIRE program this difference was $0.07 \mathrm{MPa}$. Since the engine cycle was modelled in the angle range from $-180^{\circ}$ to $180^{\circ} \mathrm{CA}$, the mean indicated pressure for the real engine was computed for the same angle range.

Figure shows the computed values of indicated efficiency. Similarly as for the mean indicated pressure, a significant difference was obtained for the results of modelling with the KIVA-3V program. The difference in indicated efficiency,

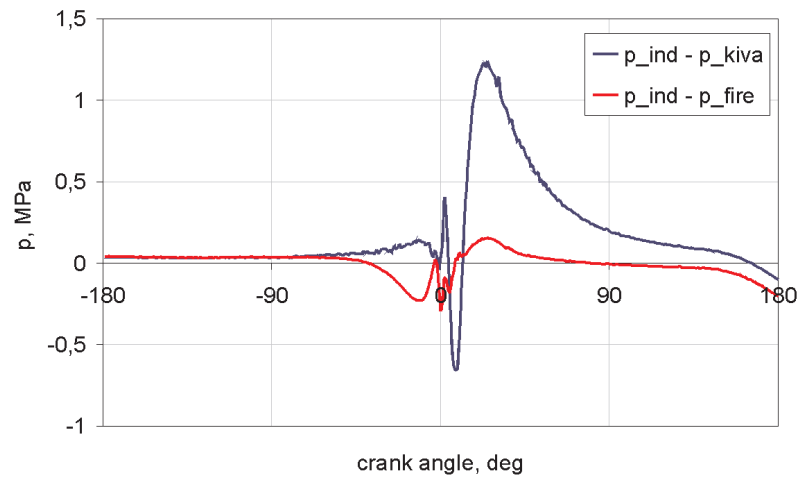

Fig. 6. The combustion pressure difference obtained by modelling with the KIVA-3V program and the AVL FIRE program

Rys. 6. Różnica ciśnienia spalania uzyskana modelowaniem programem KIVA-3V oraz AVL FIRE

odzwierciedlają przebieg ciśnienia silnika rzeczywistego. Maksymalna różnica ciśnienia spalania uzyskana programem KIVA-3V wynosiła $1,24 \mathrm{MPa}$ i wystąpiła $25^{\circ} \mathrm{OWK}$ po GMP. Dla programu FIRE różnica ciśnienia spalania wynosiła 0,15 MPa i wystąpiła przy kącie $26^{\circ}$ OWK po GMP.

Na rysunku 7 przedstawiono obliczony przyrost ciśnienia spalania dla silnika rzeczywistego oraz dla modeli. $\mathrm{Z}$ przebiegu zmian przyrostu ciśnienia można stwierdzić, że przebieg $d p / d \alpha$ uzyskany programem FIRE jest bliższy wynikom silnika rzeczywistego.

Na rysunku 8 przedstawiono różnice $\mathrm{dp} / \mathrm{d} \alpha$ uzyskane w wyniku modelowania i indykowania silnika rzeczywistego. Dla modelowania programem FIRE maksymalna różnica $\mathrm{dp} / \mathrm{d} \alpha$ wynosiła $0,14 \mathrm{MPa} 1^{\circ} \mathrm{OWK}$ po GMP, a uzyskane programem KIVA-3V wynosiła $0,3 \mathrm{MPa} 11^{\circ} \mathrm{OWK}$ po GMP.

Na rysunku 9 porównano obliczone wartości średniego ciśnienia indykowanego dla silnika rzeczywistego oraz dla modelu. Istotną różnicę pi uzyskano z modelowania programem KIVA-3V. Różnica w stosunku do silnika rzeczywistego wynosiła 0,37 MPa. Dla modelowania programem FIRE różnica ta wynosiła $0,07 \mathrm{MPa}$. Ze względu na to, że obieg
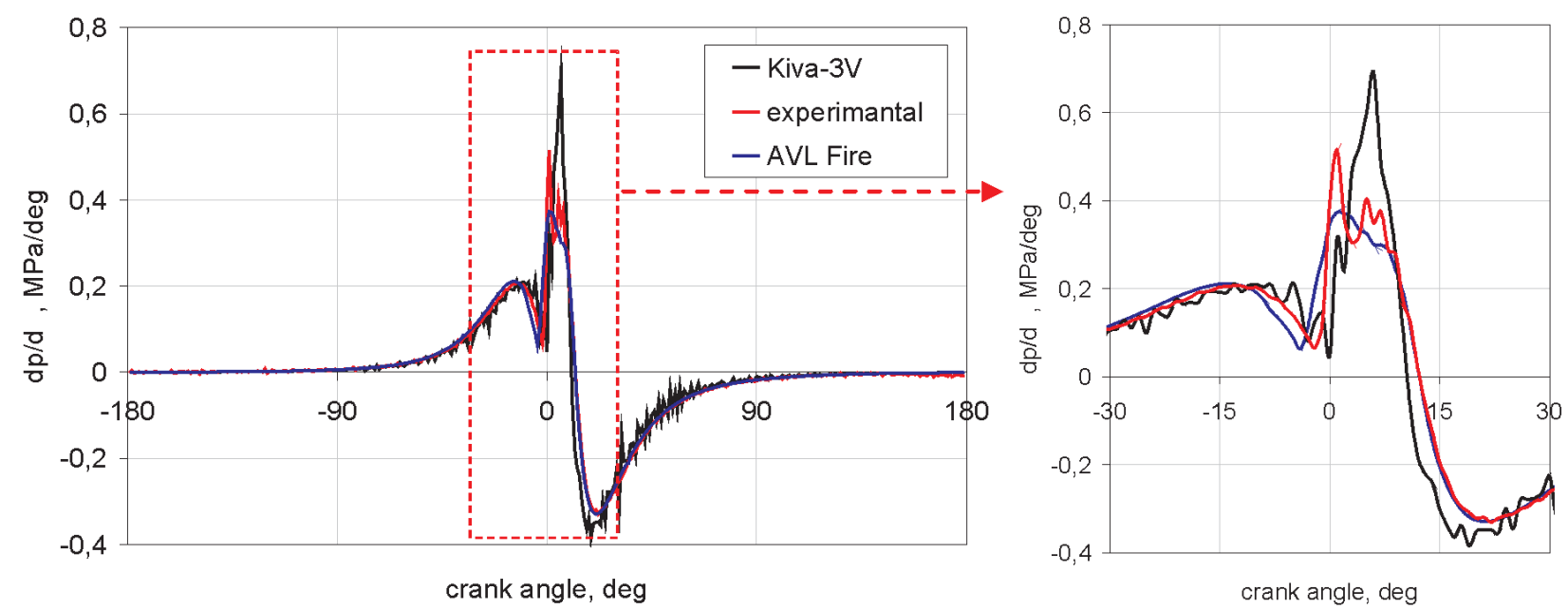

Fig. 7. Variation of pressure increment for the modelled engine

Rys. 7. Przebieg przyrostu ciśnienia dla modelowanego silnika 


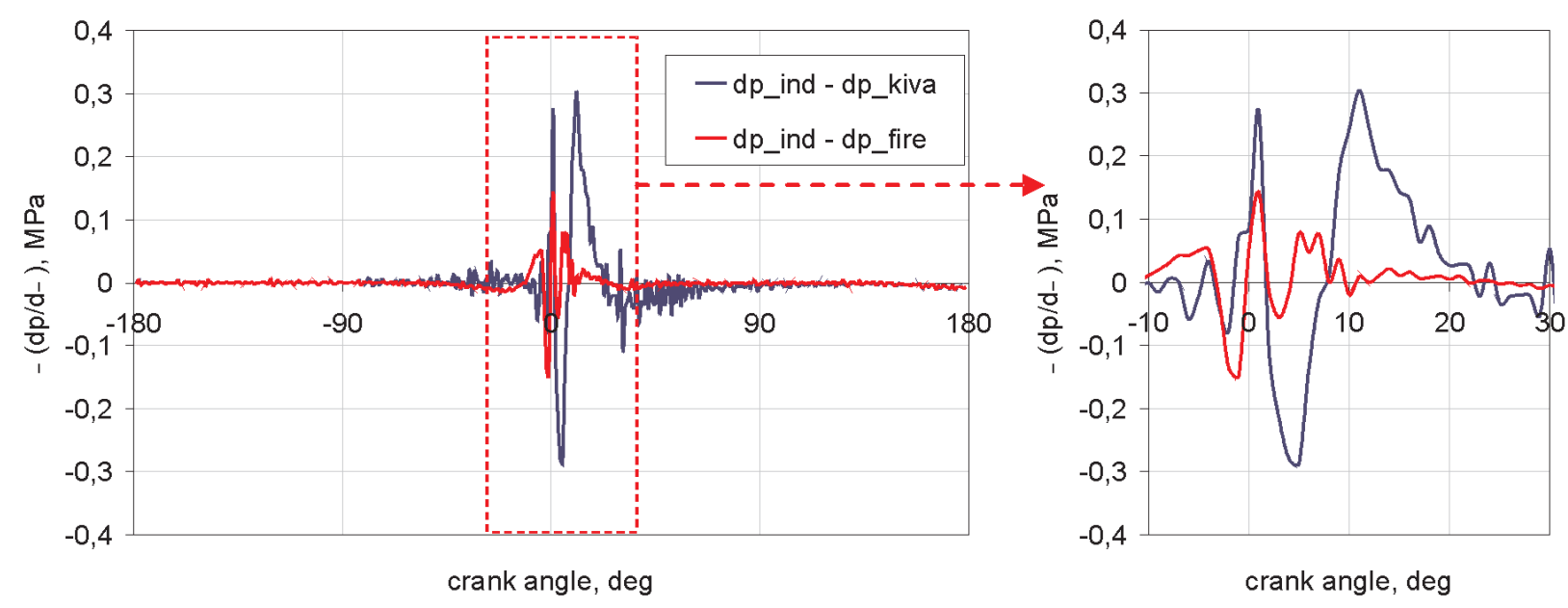

Fig. 8. Difference in pressure increment between the actual values and the values obtained from modelling with the KIVA-3V and the AVL FIRE programs, respectively

Rys. 8. Różnica przyrostów ciśnienia względem wartości rzeczywistych dla modelowania programem KIVA-3V oraz AVL FIRE

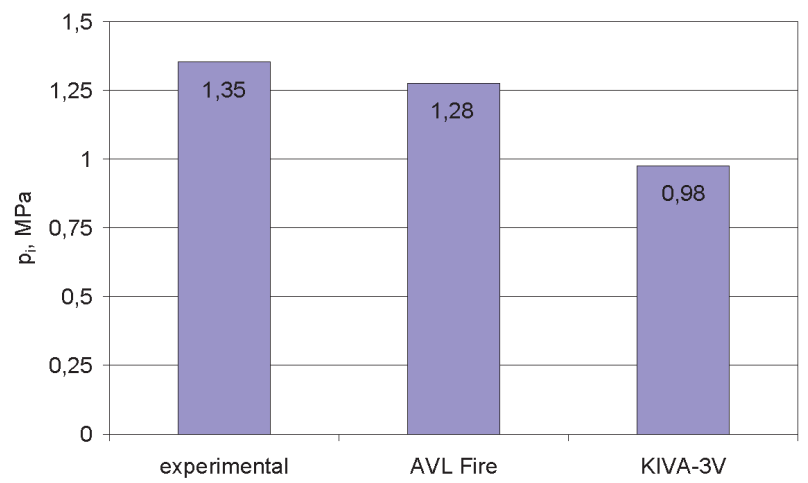

Fig. 9. Comparison of the mean indicated pressure values for the model and the real engine

Rys. 9. Porównanie wartości średniego ciśnienia indykowanego dla modelu i silnika rzeczywistego

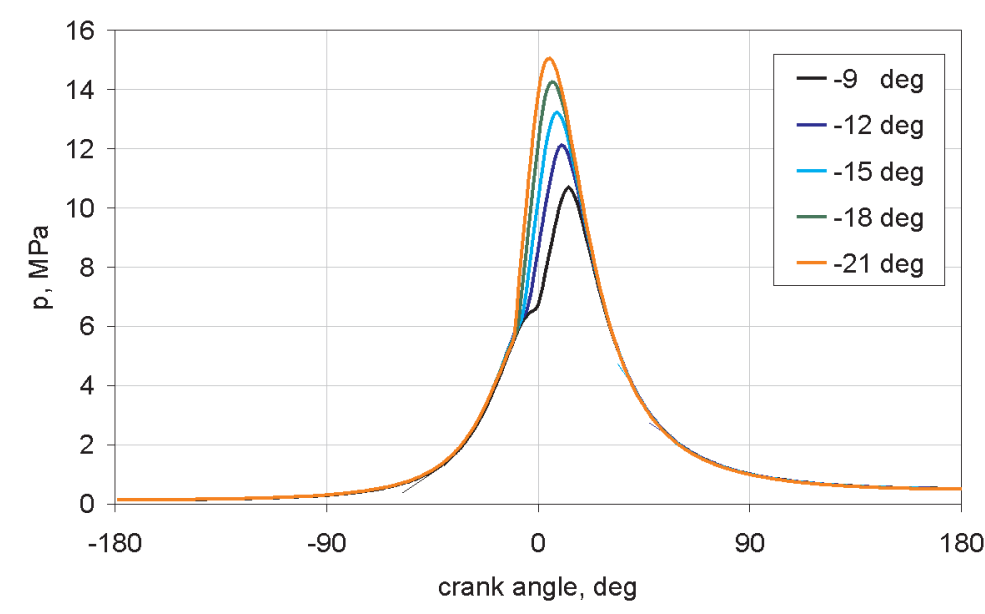

Fig. 11. Variation of combustion pressure for different injection start angles obtained from modelling with the FIRE program

Rys. 11. Przebieg ciśnienia spalania dla różnych kątów początku wtrysku modelowany programem FIRE

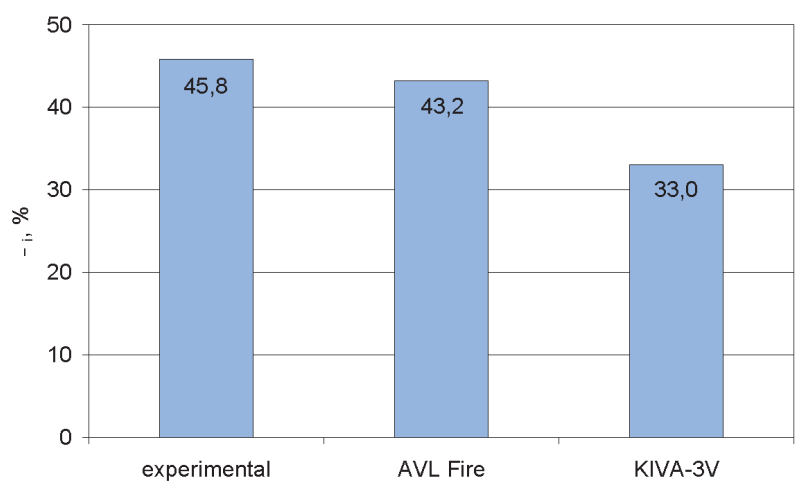

Fig. 10. Comparison of the indicated efficiency values obtained for the modelled engine

Rys. 10. Porównanie wartości sprawności indykowanej uzyskanej dla modelowanego silnika

silnika modelowano w zakresie kątów od $-180^{\circ}$ do $180^{\circ} \mathrm{OWK}$, dlatego dla silnika rzeczywistego średnie ciśnienie indykowane obliczono dla tego samego zakresu kątowego.

Na rysunku 10 przedstawiono obliczone wartości sprawności indykowanej. Podobnie jak dla średniego ciśnienia indykowanego znaczną różnicę uzyskano dla wyników modelowania programem KIVA-3V. Różnica sprawności indykowanej $\eta_{i}$ wynosiła $12,8 \%$. Znacznie lepszą zgodność wyników uzyskano dla modelowania programem FIRE, $w$ tym przypadku różnica $\eta_{i}$ wynosiła $2,6 \%$.

Silnik rzeczywisty pracuje z kątem początku wtrysku $9^{\circ}$ OWK przed GMP. Po dokonaniu weryfikacji modelu przeprowadzono modelowanie obiegu silnika w poszukiwaniu optymalnego kąta początku wtrysku. Przyjęto, że optymalną wartością kąta początku wtrysku była ta, przy której wystąpiła maksymalna praca i sprawność indykowana. 

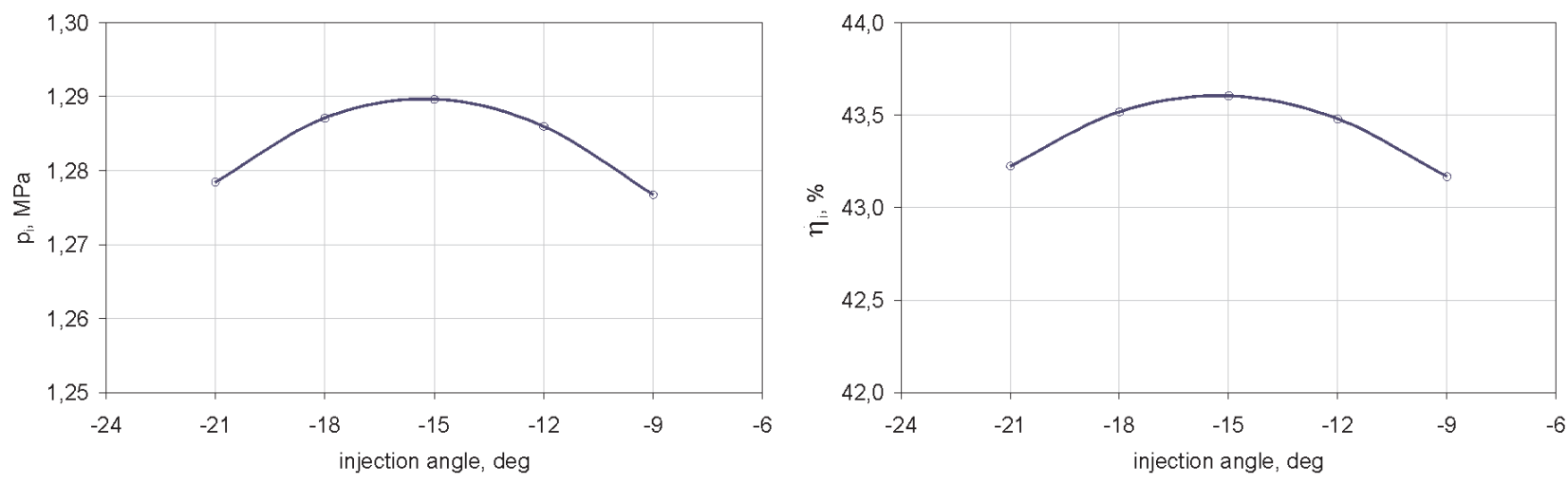

Fig. 12. Mean indicated pressure (left) and indicated efficiency (right) at different injection start angles, as modelled with the FIRE program Rys. 12. Średnie ciśnienie indykowane (lewy) i sprawność indykowana (prawy) przy różnych kątach początku wtrysku, modelowane programem FIRE

$\eta_{i}$, was $12.8 \%$. Considerably better consistence of the results was achieved for modelling with the FIRE program; in this case, the difference in $\eta_{i}$ was $2.6 \%$.

The real engine operates at an injection start angle of $9^{\circ}$ CA before TDC. After reviewing the model, modelling of the engine cycle was performed in the search for the optimal injection start angle. It was assumed that the optimal value of injection start angle was the one at which the maximum work and indicated efficiency occurred.

Figure 11 presents several pressure variation graphs obtained from modelling with the FIRE program for different fuel injection angles.

Figure 12 represents the effect of the injection start angle on the magnitudes of mean indicated pressure and indicated efficiency. For the modelled engine, it turned out that, due to the thermal cycle parameters, the optimal injection start angle is $15^{\circ} \mathrm{CA}$ before TDC. The obtained maximum values were $\mathrm{p}_{\mathrm{i}}=1.29 \mathrm{MPa}$ and $\eta_{\mathrm{i}}=43.6 \%$.

\section{Summary}

The paper has presented the results of modelling the thermal cycle of the test 6CT107 compression ignition engine, obtained using the AVL FIRE and the KIVA-3V programs. The performed simulations of the combustion process have provided information on the spatial and time distributions of selected quantities within the combustion chamber of the test engine. The numerical analysis results have been juxtaposed with the results of indicating the engine on the test stand. It has been found that the results obtained using the FIRE and the KIVA-3V programs do not coincide with the actual results; better consistence with the experimental test results has been achieved for the FIRE program's model. The difference between the maximal pressure for the engine model and the pressure value obtained from indication is, respectively, $11.5 \%$ for the KIVA-3V program and $1.4 \%$ for the FIRE program. The difference in mean indicated pressure in respect to the experiment is $27.4 \%$ for the KIVA-3V program and $5.2 \%$ for the FIRE program. The difference in indicated efficiency, $\eta_{i}$, for KIVA-3V program is $12.8 \%$, while for the FIRE program, $2.6 \%$. The simulations carried out within this work have enabled the determination of the
Na rysunku 11 przedstawiono kilka przebiegów ciśnienia uzyskanych w wyniku modelowania programem FIRE dla różnych kątów wtrysku paliwa.

$\mathrm{Na}$ rysunku 12 przedstawiono wpływ kąta początku wtrysku na wartość średniego ciśnienia indykowanego oraz na wartość sprawności indykowanej. Dla modelowanego silnika okazało się, że ze względu na parametry obiegu cieplnego optymalnym kątem początku wtrysku jest kąt $15^{\circ}$ OWK przed GMP. Uzyskane maksymalne wartości wyniosły $p_{i}=1,29 \mathrm{MPa}$ oraz $\eta_{i}=43,6 \%$.

\section{Podsumowanie}

$\mathrm{W}$ artykule przedstawiono wyniki modelowania obiegu cieplnego badawczego silnika spalinowego 6CT107 o zapłonie samoczynnym, uzyskane za pomoca programu AVL FIRE i programu KIVA-3V. Wykonane symulacje procesu spalania dostarczyły informacji na temat przestrzennych i czasowych rozkładów wybranych wielkości w komorze spalania silnika badawczego. Wyniki analizy numerycznej zestawiono $\mathrm{z}$ rezultatami indykowania tego silnika na stanowisku badawczym. Stwierdzono, że wyniki uzyskane programem FIRE i KIVA-3V nie pokrywają się z rzeczywistością, a lepszą zgodnością z rezultatami badań eksperymentalnych charakteryzuję się model programu FIRE. Różnica maksymalnego ciśnienia dla modelu silnika, w stosunku do wartości ciśnienia uzyskanego z indykowania wyniosła odpowiednio: dla programu KIVA-3V 11,5\%, a dla programu FIRE 1,4\%. Różnica wartości średniego ciśnienia indykowanego $\mathrm{w}$ odniesieniu do eksperymentu wyniosła: dla programu KIVA-3V 27,4\%, dla programu FIRE 5,2\%. Różnica wartości sprawności indykowanej $\eta_{i}$ wynosiła dla programu KIVA-3V $12,8 \%$, a dla programu FIRE 2,6\%.

Przeprowadzone w ramach pracy symulacje umożliwiły wyznaczenia optymalnego kąta wyprzedzenia wtrysku paliwa dla modelu silnika, który wyniósł $15^{\circ} \mathrm{OWK}$ przed GMP. Wartość ta okazała się różna od wartości kąta $9^{\circ}$ OWK przed GMP, z którym pracuje silnik rzeczywisty. Fakt ten wymaga weryfikacji na silniku eksperymentalnym, co będzie uwzględnione w kolejnych pracach badawczych. 
The accuracy of modelling of the thermal cycle...

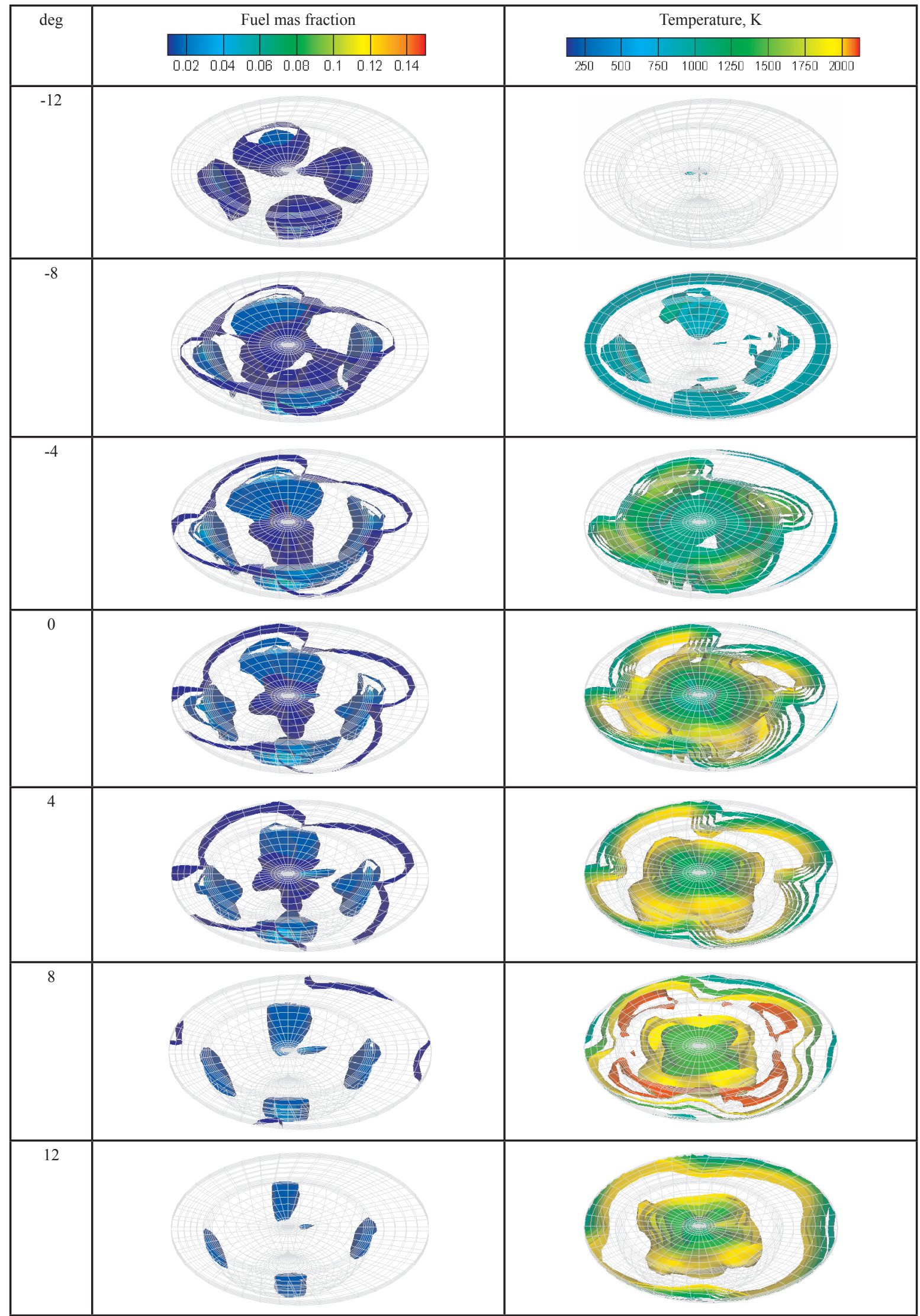

Fig. 13. Spatial distribution of fuel and temperature in the combustion chamber, as modelled with the FIRE program. Injection start angle $-15^{\circ} \mathrm{CA}$ before TDC

Rys. 13. Przestrzenny rozkład paliwa w komorze spalania oraz temperatury modelowane programem FIRE. Kąt początku wtrysku $-15^{\circ}$ OWK przed GMP 
optimal fuel injection advance angle for the engine model, which amounts to $15^{\circ} \mathrm{CA}$ before TDC. This value has turned out to be different from the angle value of $9^{\circ} \mathrm{CA}$ before TDC, at which the real engine operates. This fact needs to be verified on an experimental engine, which will part of subsequent research works.

In summary, it can be stated that for the investigated case of modelling the thermal cycle of the 6CT107 compression ignition engine, the AVL FIRE program has turned out to be a better tool, as it has provided better consistence of the modelling results with the real engine indication results.
Podsumowując, można stwierdzić, że dla badanego przypadku do modelowania obiegu cieplnego silnika 6CT107 o zapłonie samoczynnym lepszym narzędziem okazał się program AVL FIRE, ponieważ dzięki niemu uzyskano dobrą zgodność wyników modelowania z wynikami indykowania silnika rzeczywistego.

Paper reviewed/Artykut recenzowany

\section{Bibliography/Literatura}

[1] Amsden A.A.: KIVA-3V, A Block-Structured KIVA Program for Engines with Vertical Or Canted Value. Los Alamos National Laboratory LA-UR-97-689, 1997.

[2] Amsden A.A.: KIVA-3V: A KIVA Program with Block-Structured Mesh for Complex Geometries, Los Alamos National Laboratory, LA-12503-MS, 1993.

[3] Amsden A.A., O'Rourke P.J., Butler T.D.: KIVA-II, A computer program for Chemically Reactive Flows with Sprays. Los Alamos National Laboratory LA-11560-MS, 1989.

[4] AVL FIRE, VERSION 2009ICE Physics \& Chemistry. Combustion, Emission, Spray, Wallfilm. Users Guide, 2009.

[5] Baumgarten C.: Mixture Formation in Internal Combustion Engines. Springer-Verlag Berlin Heidelberg 2006.

[6] Binesh A.R., Hossainpour S.: Three dimensional modeling of mixture formation and combustion in a direct injection heavyduty diesel engine, World Academy of Science, Engineering and Technology 41, p. 207-212, 2008

[7] Colin O., Benkenida A.: The 3-Zones Extended Coherent Flame Model (ECFM3Z) for Computing Premixed/Diffusion Combustion. Oil \& Gas Science and Technology 2004.

[8] Dillies B., Marx K., Dec J., Espey Ch.: Diesel Engine Combustion Modeling Using the Coherent Flame Model in Kiva-II. SAE Paper Number: 930074, 1993.

[9] Gunabalan A., Tamilporai P., Ramaprabhu R.: Effects of injection timing and EGR on DI diesel engine performance and emission - using CFD, Journal of Applied Sciences 10 (22), p. 2823-2830, 2010.

[10] Hélie1 J., Trouvé A.: A modified coherent flame model to describe turbulent flame propagation in mixtures with variable composition. Proceedings of the Combustion Institute, Volume

Prof. Karol Cupiał, DSc., DEng. - Professor in the Faculty of Mechanical Engineering and Computer Science of Częstochowa University of Technology.

Prof. dr hab. inż. Karol Cupiat - Profesor na Wydziale Inżynierii Mechanicznej i Informatyki Politechniki Częstochowskiej.

e-mail: cupial@imtits.pcz.czest.pl

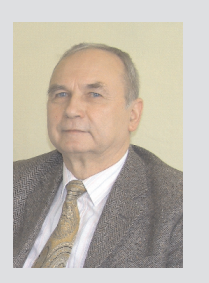

Mr. Arkadiusz Jamrozik, DEng. - doctor in the Faculty of Mechanical Engineering and Computer Science of Częstochowa University of Technology.

Dr inż. Arkadiusz Jamrozik - adiunkt na Wydziale Inżynierii Mechanicznej i Informatyki Politechniki Częstochowskiej.

e-mail: jamrozik@imtits.pcz.czest.pl
28, Issue 1, 2000, p. 193-201. Revue de l'Institut Français du Pétrole.

[11] Heywood J.B.: Internal combustion engine fundamentals. McGraw-Hill, 1988.

[12] Kusaka J., Daisho Y.: Simulating combustion and exhaust gas emissions in a DI diesel engine by using a CFD code combined with detailed chemistry, Journal of KONES Internal Combustion Engines 2003, vol. 10, No 1-2, 2003

[13] Musculus M.P., Rutland C.J. : Coherent flamelet modeling of diesel engine combustion. Combustion science and technology. 1995, vol. 104, no 4-6, p. 295-337.

[14] Schweitzer P.: The tangent method of analysis of indicator cards of internal combustion engines. Bulletyn nr 35, Pennsylvania State Univeristy, September 1926.

[15] Kort R.T., Mansouri H., Heywood J.B., Ekchian A.: Dividedchamber diesel engine. Part II. Experimental validation of a predictive cycle-simulation and heat release analysis. SAE Papers, 1982, nr 820205.

[16] Rychter T., Teodorczyk A.: Modelowanie matematyczne roboczego cyklu silnika tłokowego. PWN, Warszawa 1990.

[17] Szwaja S, Jamrozik A.: Analysis of Combustion Knock in the SI Engine. Silniki Spalinowe/Combustion Engines, Mixture Formation Ignition \& Combustion, Nr 2009-SC2, June 2009.

[18] Warnatz J, Maas U., Diable R.W.: Combustion. Physical and Chemical Fundamentals, Modeling and Simulation, Experiments, Pollutant Formation. Springer, 2006.

[19] Tatschl R., Priesching P., Ruetz J.: Recent Advances in DI-Diesel Combustion Modeling in AVL FIRE - A Validation Study. International Multidimensional Engine Modeling User's Group Meeting at the SAE Congress April 15, 2007 Detroit, MI.

Mr. Wojciech Tutak, DEng. - doctor in the Faculty of Mechanical Engineering and Computer Science of Częstochowa University of Technology.

Dr inż. Wojciech Tutak - adiunkt na Wydziale Inżynierii Mechanicznej i Informatyki Politechniki Częstochowskiej.

e-mail: tutak@imtits.pcz.czest.pl

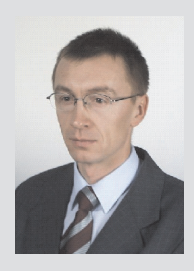

Mr. Arkadiusz Kociszewski, DEng. - doctor in the Faculty of Mechanical Engineering and Computer Science of Częstochowa University of Technology.

Dr inż. Arkadiusz Kociszewski - adiunkt na Wydziale Inżynierii Mechanicznej i Informatyki Politechniki Częstochowskiej.

e-mail: kocisz@imtits.pcz.czest.pl

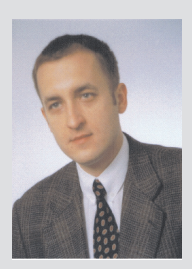

